\title{
International Social Medicine between the Wars Positioning a Volatile Concept
}

\author{
Iris Borowy
}

The League of Nations Health Organisation (LNHO) was the first worldwide health organisation with a comprehensive mandate which enabled it to address a wide, almost unlimited, range of topics. This freedom of action proved a blessing as well as a curse. During the first decade of its existence the LNHO became involved in a large number of diverse problems without an overriding issue that would have lent direction and profile to their overall work. In the 1930 s, it seemed to have found such an issue in social medicine. ${ }^{1}$

Social Medicine was an important topic in a number of countries in the early twentieth century. Though it had its origins in the nineteenth century, it reached its apex between 1930 and about 1948. It remained an elusive concept, which different people could interpret in different ways but as a central defining trait it had "at its core ... a critical approach to health care that stressed the social determinants of disease." ${ }^{2}$ This principle fairly described a number of large-scale studies organised within the LNHO, which came to overshadow all other areas of activities in their

1 See Iris Borowy, "Die Gesundheitsorganisation des Völkerbundes 1929-39”, in Sylvain Schirmann, ed., Organisations Internationales et Architectures Européennes 1929-1939. Actes du colloque de Metz - Mai 2001, Publications du Centre de Recherche Histoire et Civilisation de l'Europe Occidentale de l'Université de Metz, no. 23, 2003, pp. 181-183; Marta A. Balinska, Une Vie pour l'Humanitaire (Paris, 1995), p. 121; Neville M. Goodman, International Organizations and Their Work (Edinburg \& London, 1952; 2. revised edition 1971), p. 114.

2 About social medicine see Matthew R. Anderson, Lanny Smith, and Victor W. Sidel, "What is Social Medicine?", Monthly Review, 56 (2005) 8, 27-34; Edward T. Morman, "George Rosen, Public Health and History", biographical essay in George Rosen, A History of Public Health (Baltimore, 1993), p. xix; Gabriele Moser and Jochen Fleischhacker, "People's health and Nation's body. The modernisations of statistics, demography and social hygiene in the Weimar Republic"; and Lion Murard and Patrick Zylberman, "French social medicine on the international public health map in the 1930s," both in Esteban Rodríguez-Ocaña, ed., The Politics of the Healthy Life, an International Perspective, (Sheffield, 2002), pp. 151-179 and pp. 197-218; Dorothy and Roy Porter, "What was Social Medicine? An Historiographical Essay," Journal of Historical Sociology, 1(1989), 90-106. 
second decade. However, there was not one coherent super-program but what may at first sight appear like a somewhat odd assortment of separate fields of work. The largest studies focussed on rural hygiene, on health during an economic depression, nutrition and housing. Further schemes were planned or begun on physical fitness and clothing but never fully implemented because the outbreak of the Second World War put an end to such ambitious plans and, in fact, to most LNHO activities. $^{3}$

Why were these topics chosen? Where did they come from and how did they fit into the scenery of international health work? And what, in retrospect, is their historical significance? None of them was imposed by some superior body. Invariably, they originated from proposals by governments, and work on them was conducted with and through experts from many countries, who took part in international meetings, wrote reports and conducted studies in their countries, often with public funding, always with governmental approval. Clearly, the large-scale international program on social medicine of the LNHO satisfied some need felt in many capitals. However, in the process, the studies tended to gain a life of their own, and the LNHO corporate identity certainly influenced how the issues were approached, what questions were asked and, by extension, what findings resulted. In the end, the outcome was more than merely the sum of collected national efforts and not necessarily what most governments may have hoped to gain.

Yet, as mentioned, the studies did not develop in isolation. They formed an integral part of international - mostly European - medical discourse, and they grew organically from scientific and political developments of the time. Significantly, social medicine could gain ground because bacteriology was losing its dominant grip over the scientific scene. By 1917, the pathogens of all major infectious diseases, except influenza, had been discovered, and lacking further causative agents that could be identified, research into disease etiology had to expand. ${ }^{4}$ While bacteriology developed on into the study of sera and, eventually, antibiotics, scientific interest was also receptive for new areas with a promise of discoveries and spectacular findings. One such area was nutrition. While the topic had already attracted some research interest in the nineteenth century, the period around the First World War was a time of major breakthroughs. In 1912, Polish-born biochemist Casimir Funk presented his theory of four nutritional diseases (beriberi, pellagra, rickets and scurvy). By then, studies into those parts of food necessary in

3 In addition, there were other topics with a social medical angle, like studies on infant welfare, social insurance etc., which, however, never achieved the status of major programs and did not form part of the main agenda of the 1930s.

4 Andrew Cliff, Peter Haggett and Matthew Smallman-Raynor: Deciphering global epidemics. Analytical approaches to the disease records of world cities, 1888-1912, (Cambridge, 1998), pp. 22-23. 
minute quantities to ensure health was well underway, and most vitamins were identified in the 1920s and 1930s. ${ }^{5}$

At the same time, the Epidemiologic Transition in Europe directed attention away from infectious to chronic diseases. There is still no consensus on the precise reasons for the transition, and it did not happen simultaneously in all parts of Europe, let alone the rest of the world. ${ }^{6}$ Yet it is safe to say that by the interwar years most European countries had experienced or were experiencing a marked decline of the mortality rate and a resulting increase in life expectancy. This development was paralleled by a transition of the disease spectrum, in which infectious diseases were replaced by chronic diseases as the prime cause of death. ${ }^{7}$ These changes influenced not only the spectrum of prevalent diseases but also the geographical distribution of morbidity and mortality. As infectious diseases came increasingly under control and medical care was beginning to be truly effective, living in a city with high population density and medical institutions became relatively less of a health hazard than an asset. Probably for the first time in human history urban mortality began to equal rural mortality. In fact, in 1931 it was found that crude rural mortality rates were higher than urban rates in Germany, Switzerland, the Netherlands, Sweden, Bulgaria, Belgium and Italy. ${ }^{8}$ Between the two world wars, increasing urbanisation was being felt in Europe, but most countries

5 Kenneth Carpenter, "History of Nutrition - A Short History of Nutritional Science," Part two, The Journal of Nutrition, 133(2003), 4, 975-984, and Part 3, The Journal of Nutrition, 133(2003), 10, 3023-3032; Kenneth J. Carpenter: Protein and Energy. A Study of Changing Ideas in Nutrition, (Cambridge, 1994); Harmke Kamminga and Andrew Cunningham, eds., The Science and Culture of Nutrition, 1840-1940 (Amsterdam, 1995); Stephen V. Beck, "Scurvy: Citrus and Sailors", "Pellagra: the disease of Three Ds", "Beriberi: A Plague of Rice, and Rickets: Where the Sun doesn't Shine”, all in Kenneth F. Kiple, ed., Plague, Pox \& Pestilence (London, 1999), pp. 6873 and pp. 118-135.

6 Improved nutrition, sanitary reform, the isolation of infected in hospitals or poor people's homes, an improved economic status of workers, a reduction in crisis, epidemic years, increasing benefits of urbanization, climatic influences and, after all, medical advances, have all been suggested as reasons. Most probably, it was a mixture of several causes which provoked these changes. For systematic surveys see Sylvia Hähner-Rombach, Sozialgeschichte der Tuberkulose (Stuttgart, 2000), pp. 74-83; Cliff / Haggett / Smallman-Raynor, Deciphering global epidemics., pp. 134-8; Roger Schofield and David Reher, "Introduction", in Roger Schofield and David Reher, eds., The Decline of Mortality in Europe (Oxford, 1991), pp. 1-17. See also contributions in their edited volume on various causes of mortality decline.

For the concept of the Epidemiologic Transition, see Abdel R. Omran, "The Epidemiologic Transition. A theory of the Epidemiology of Population change", Milbank Memorial Fund Quarterly, 49 (1971), 1, 1-42.

7 Paul Weindling, "From infectious to chronic diseases: changing patterns of sickness in the nineteenth and twentieth centuries", in Andrew Wear, ed., Medicine in Society (Cambridge, 1992, reprinted 1994), pp. 303-316; Alex Mercer, Disease, Mortality and Population in Transition (Leister, 1990).

8 Knud Stouman, Mortality Conditions in Rural Europe, C.H. 1052, reprinted from the Monthly Epidemiological Reports May and June 1931, Geneva. 
were still dominantly rural. ${ }^{9}$ Given the combination of these factors, research interests would naturally veer towards the conditions of long-term health status (as opposed to acute infections), nutrition and increasingly towards rural areas.

Political and economic events added their respective imprints. The Economic Crash of 1929 and the ensuing Depression forced public attention on mass unemployment, poverty and misery. Pauperisation was widespread, not only in the cities but also in the countryside, as prices for agricultural products fell to a fraction of pre-war levels. ${ }^{10}$ The depression exacerbated social conditions which had already given cause for concern before. Nutrition had seemed far from perfect, and disastrous overcrowding in several countries gave rise to governmental public construction programs, which conditioned governments to see value in discussions of these issues.

Meanwhile, democracies, which had been the most widespread form of government in Europe after the First World War, gradually gave way to a growing list of dictatorships which tended to decrease the concern of those governments for individual well-being but to increase their interest in collective health and prowess. In addition, this interest fed on the general climate of the time: the intense nationalism and the tangible competition between the ideologies that came to determine political life in Europe: democracy, communism and fascism. Even before the outbreak of open warfare there was a sense of a violent Darwinian assessment, of determining which nation and which world-view was the strongest, the most viable, the best. Public health was important, both as a measurement of relative success, and as a potential resource for actual warfare. ${ }^{12}$ This situation was fertile ground for governmental concern about public health in general, and specific ideologies added their specific angles. Thus, the quasi mythological idealisation of earth and peasantry, prevalent in fascism, doubtlessly added to a concern about rural hygiene. ${ }^{13}$ Taken together, these factors go far to explain the choice of specific topics of social medicine within the LNHO: rural hygiene, health during an economic depression, nutrition and housing. ${ }^{14}$

9 Gerold Ambrosius and William H. Hubbard, Sozial- und Wirtschaftsgeschichte Europas im 20. Jahrhundert (Munich, 1986) pp. 41-46.

10 Charles P. Kindleberger, Die Weltwirtschaftskrise. Geschichte der Weltwirtschaft im 20.Jahrhundert, Vol. 4, (München, 1973, 3rd edition 1983), p. 87.

11 Iris Borowy, "World Health in a Book", in Iris Borowy and Wolf D. Gruner, eds., Facing Illness in Troubled Times (Berlin, 2005), p. 118; Colin G. Pooley, ed., Housing Strategies in Europe, 1880-1930, Leicester 1992.

12 Mark Mazower, Der dunkle Kontinent (Frankfurt a. M., 2002), pp. 117-156, [Engl. original: Dark Continent. Europe's Twentieth Century (London, 1998)].

13 Andrew Heywood, Political Ideologies (2nd ed., New York, 1998), 233-234; Joachim Radkau, Natur und Macht. Eine Weltgeschichte der Umwelt (Munich, 2000), pp. 294-296

14 Physical Fitness and Clothing had been planned as additional topics but work on them never got past initial preparations before the outbreak of World War II. Other topics that could 


\section{Rural Hygiene}

The topic of rural hygiene was introduced into the LNHO agenda simultaneously by the Governments of India, Poland and Spain in 1928. Work began the usual collection of data and national position papers and through several international study tours. ${ }^{15}$ It received a substantial boost with a Spanish proposal to organise a European conference on health in rural areas in the summer of $1930 .{ }^{16}$ A few weeks later, a conference on Rural Health Centres took place under LNHO auspices in Budapest. ${ }^{17}$ The concept of "health centres" was of recent origin and had initially described centres for specific tasks, like childcare or anti-tuberculosis work, mostly in large cities in England and the USA. After the First World War, however, an impressive number of such institutions developed in many countries, particularly the dominantly rural heirs of the Habsburg Empire, Austria, Yugoslavia, Czechoslovakia and Hungary, but also Poland and others, and their characters varied according to local circumstances and needs. The discussions in Budapest about their various forms and functions soon expanded into deliberations on rural healthcare in general. Though views differed on details, the talks gradually identified two major tasks for an improvement of rural healthcare:

1. getting healthcare services to rural people, and

2. getting rural people to healthcare services.

Neither was easy. The first task was complicated by several factors, at the most basic level, that of transport. Since by definition rural people lived spread out, visits by doctors or nurses entailed travel, often over bad or non-existent roads which prevented the effective use of cars and bicycles even when exceptionally doctors or nurses had access to them. Improving these conditions required money, lots of it, and during the early 1930s the necessary sums simply were not available. This scar-

be termed part of social medicine, such as infant welfare or social insurance, had already received some attention during the 1920s, but work on them was scant and patchy, and they never developed into coherent programs. Therefore, this paper will focus on the four themes named above.

15 Annual Report of the Health Organisation for 1928, A.8.1929.III (C.H. 788), 18 April 1929, pp.5 and 50; Annual Report of the Health Organisation for 1929, A.9.1930.III (C.H.863), July 1930, pp.44-45.

16 Convocation of a European Conference on Rural Hygiene: Proposal of the Spanish Government, C.555.1930.III, Official Journal, November 1930, p.1515; cf. Minutes of the Health Committee, 29 Sept to 7 Oct 1930, C.627.M.248, pp. 26-28.

17 For the entire discussion on healthcare centres, see: Note on Health Centres, C.H./934(1), 23 Oct 1930; M. Stellar, Public Health Nursing Service of a Health Centre, C.H. 940, 23 Oct 1930; W. Chodzko, Le Centre Rural d'Hygiène et d'Assistance Sociales et l'Assainissement Effectif de la Campagne, C.H. 925, 2 Oct 1920; Schedule on Rural Health Centres, 9 Oct 1930, C.H. 933, all for: Conference on Rural Health Centres, Budapest, October 27th - 30th, 1930; Memo for the Second Session of the Preparatory Committee, C.H. 948, 29 Nov 1930. 
city of financial resources not only made it difficult to get doctors to their patients once they were in the area but to get doctors into rural regions in the first place. Being a country doctor usually meant working longer hours under more difficult circumstances for less pay and prestige than colleagues in urban areas, and with little chance of career advancement. Many university trained doctors were understandably hesitant to choose this professional path. Obviously there were several possibilities of how to entice doctors into rural areas but each involved more farreaching decisions about the general concepts of public health systems: if doctors were to get more money, where should it come from? (From central administrations? From the regional government? From private patients or, since it was unrealistic to expect peasants to pay high fees, from private health insurances?) If doctors were to be coerced into working in rural areas for all or part of their working lives, who should be responsible for organising what type of program? Should doctors be generally allocated their place of work, or should spending a certain period merely be part of their instruction or career? These questions had serious repercussions since they potentially entailed regulating academic training or bringing a liberal career under state planning and control.

Thus, inevitably, these decisions implied choices about not only patterns of rural administration but of the economic and political systems of the state at large. Besides, solving these problems was only half of the task, since having healthcare services in a rural area did not mean that people would use them. In fact, LNHO studies showed that in most countries, rural populations tended to regard visits to doctors as rare emergency events, occasioned only in extraordinary moments when all traditional remedies had failed. Obviously, this attitude ran counter to all efforts to establish a modern healthcare system with early diagnosis and preventive services. Once more, one central problem was financial. Most rural people were poor, particularly during depression times, and only a small minority of rural labourers was insured. Another part of the problem was psychological. Regular visits to doctors simply were not part of traditional ways of rural life and contradicted people's instincts. Thus, education of "ignorant country folks" was found an urgent necessity. Yet, it was not only farmers' minds that needed changing. Often, universitytrained urban doctors and farmers with little or no formal education, came from such different worlds, speaking different dialects and sociolects, that relationships of mutual trust or even effective communication were difficult. Therefore, it was essential to involve other people in healthcare particularly nurses and midwives, who tended to come from the same areas and social groups as their patients.

Generally speaking, participants felt that "the rural health centre as defined by the conference was considered to be the best method of organising the health ser- 
vices in rural districts." ${ }^{18}$ In order to be effective, however, it was important that these centres should not merely focus on health in a narrow sense but as a place of reference and counselling for a number of health-related concerns, particularly maternal and infant welfare. Beyond that, it was desirable to find ways of social contextualisation so that health centres should serve various social functions within communities as well as health in a narrow sense. Such multifunctionalism was not only to increase the acceptance of the centre in its community but to also reflect a holistic understanding of health which could not be separated from other spheres of everyday life. Thus, health education was at the same time part of education about nutrition, home economics, hygiene, childcare, education and a large number of topics that would help manage a healthy life, including even basic skills as literacy. ${ }^{19}$

These findings were adopted as part of a long list of recommendations, which a committee of international experts prepared in May 1931 for discussions at the European Conference on Rural Hygiene in July. ${ }^{20}$ Representatives of twenty-five European States took part as well as observers from eight extra-European countries. For its time, it was impressively large. It demonstrated both the vivid interest in and the intimidating breadth of the issue.

After ten plenary and many committee meetings, the participants endorsed almost verbatim the recommendations drafted by the preparatory committee in May:

- In the smallest rural settlement, people were to have access to first aid and a doctor's services.

- Effective medical assistance in rural districts demanded the collaboration of public authorities, the medical profession, health insurance institutions, mutual benefit associations, private agencies etc. Careful planning and coordination was necessary to avoid duplication of work.

- Public authorities were to ensure that the entire population benefited from effective medical assistance.

- Health insurance was helpful, and where it had not yet been established rationally organised free medical assistance might intervene.

18 Memo for the Second Session of the Preparatory Committee, C.H. 948, 29 Nov 1930, p. 3 .

19 See footnote 17.

20 Technical Recommendations by the Preparatory Committee." Extracts from the Report of the Preparatory Committee, Document C.H. 1045, in European Conference on Rural Hygiene, Vol. II, Minutes, C.473.M.202.1931.III., pp. 142-161. 
- The State was to either administer or supervise a rural health system. Both could give good results, and the form best suited depended on the general administration of the country.

- Rural health systems were to include programs on infectious disease control, campaigns against social diseases, maternal and infant welfare, sanitation, hygiene of milk and foods, education in hygiene, and sanitary supervision of medical institutions.

- Effective work needed accurate statistic on medical, social and economic conditions.

- An intelligent system of primary and secondary health centres was recommended highly.

- There was an urgent need for effective sanitation, especially as regards sewage, manure and garbage.

- The quality of water supplies depended on the protection of the source, inspection and supervision and - where necessary - purification.

- There was an urgent need for all aspects of rural housing.

- Further studies were recommended under LNHO auspices for a number of topics, including, public health nursing schools, the cost of rural health and medical services, treatment of garbage and manure to prevent fly-breeding, water analysis methods, the hygiene of milk and typhoid infections. ${ }^{21}$

Not all of the topics were actually adopted for detailed studies, but a surprising number were, and several of them developed into formidable programs in their own right.

Typhoid fever was a case in point. Surveys and studies of several schools of hygiene found that the disease was more widespread than expected and, indeed, a serious health problem. While the epidemiology of typhoid fever was as yet unclear, attention turned to flies whose alternate visits to manure heaps and kitchens made them a likely culprit and, in any case, a health threat. ${ }^{22}$ Thus, the search for ways to keep flies from houses and manure attracted considerable attention. A number of LNHO reports documented experimentation on various forms of enclosed manure

21 European Conference on Rural Hygiene, C.473.M.202.1931.III, in Official Journal, Sept 1931, pp.1885-1898.

22 Typhoid Fever in Rural Areas. Results of the enquiries so far effected in pursuance of the recommendations of the European Conference on Rural Hygiene, C.H. 1276, 25 Oct 1937; Typhoid Fever in Rural Areas, C.H. 1286, 2 Nov 1937; Draft Report of the Sub-Committee on Rural Typhoid, C.H./Hyg.rur/Typh./13, 26 Nov 1937. 
heaps and fly-proof homes. ${ }^{23}$ The latter topic tied into the already ongoing studies into the role of housing in malaria and efforts to keep houses free from mosquitoes. $^{24}$

Inevitably, housing and sanitation developed into a strong focus. The LNHO distributed information from national studies including very practical recommendations on how to construct a farmhouse so that water used for washing would not mix with drinking water, and human and animal waste would be at a safe distance. ${ }^{25}$ The topic continued to grow, and the LNHO used every opportunity to reach as wide an audience as possible. In mid 1937 the LNHO participated in the International Exhibition in Paris with an exposition on rural housing. ${ }^{26}$ In December 1938 a Report on Rural Housing summarised findings. ${ }^{27}$

\section{Housing}

In fact, by that time the issue had already outgrown the limits of rural hygiene. The course of considerations had increasingly called into question why an issue of such obvious relevance to general health as housing should be limited to rural populations.

In addition, studies on the economic crisis during the fall of 1932 called attention to the extent to which housing conditions of unemployed had an impact on their health. During 1934, calls in the League Assembly for an adoption of the issue within the Health Organisation prompted first moves to collect material on housing conditions in various countries. The Health Section provided guidelines to aid national administrations conduct studies in their countries. ${ }^{28}$ They also recommended establishing national housing committees both for conducting research and for subsequent consultation. This idea was readily accepted in several countries, so that, in fact, after a while, some governments considered turning them into perma-

23 Jacques Parisot and L. Fernier, "The Best Methods of treating Manure-Heaps to prevent the Hatching of Flies", Quarterly Bulletin of the Health Organisation, Vol. III (1934), 1-31; Edm. And Et. Sergent, "Fly-free Manure Heaps", ibid. 299-303; Mathias Thomsen, "Fly Control in Denmark", ibid., 304-324.

24 S. R. Christophers and A. Missiroli, Report on Housing and Malaria, Quarterly Bulletin of the Health Organisation of the League of Nations, Vol II, no. 3 (1933), 357-482.

25 H. A. Whittaker, Water Supply and Sewage Disposal for the Isolated Dwelling, C.H./Com.Hab./70, R 6128/8A/35690/20823.

26 Exposition Européenne de l'Habitation Rurale, Sous la signe de la Société des Nations à l'Exposition Internationale de Paris 1937, League of Nations Archive (LONA), R 6122/8A/22858/20823.

27 M Vignerot, "La maison et l'aménagement ruraux", Quarterly Bulletin of the Health Organisation of the League of Nation, Vol. VIII (1939), 92-151.

28 Studies on Housing, C.H. 1155 (revised), 6 June 1935. 
nent bodies. ${ }^{29}$ However, establishing the status quo was only the first step towards systematic studies aiming at defining physiological needs, and in October 1935, the LNHO Health Committee established a Housing Committee. Studying the topic, however, turned out particularly difficult. It was virtually impossible to identify objective measurements for healthy housing (as opposed to a subjective feeling of comfort), and all issues were interdisciplinary and intertwined in a messy way and had a tendency to broaden into the sphere of public policy. After intensive discussions, the Committee established a list of nine sub-topics. The first four focussed primarily on conditions within buildings:
a. environmental condition
b. noise
c. insulation
d. lighting

But results, published in two reports in 1937 and 1938, showed that the situation inside a building could not meaningfully be separated from that outside. ${ }^{30}$ So it was only a matter of degree when further studies moved attention beyond the realms of the individual house to its environment:
e. space planning
f. air pollution
g. water, sewage, waste disposal

The Housing Committee prepared reports on these issues in the summer of 1939, a few weeks before the outbreak of World War II. A detailed schedule for further studies on

h. administrative and legislative aspects of the hygiene of housing

i. the definition of urban and rural housing, or healthy cities and countryside and on conditions in tropical areas became immaterial. ${ }^{31}$

The program never succeeded in producing minimal standards or final conclusions. But the series of reports did issue a fair number of recommendations which served a similar function in calling for - among others -

29 Rapport de la commission de l'habitation au bureau du comite d'hygiene, undated (ca. Jan 1936), LONA, R6122/8A/20823/20823.

30 "Rapport de la Commission de l'Habitation", in Bulletin de l'Organisation d'Hygiène, Vol. VI (1937), 543-592; "L'insolation de l'éclairage Naturel et Artificial des Points de Vue de l'Habitation et de l'Urbanisme", in Bulletin de l'Organisation d'Hygiène, Vol. VII (1938), 628-656.

31 "Rapport de la Commission de l'Hybitation sur les Rèunions tenues du 26 juin au 1er juillet 1939”, in Bulletin de l'Organisation d'Hygiène, Vol. VIII (1939), 789-858. 
- low-noise buildings (using suitable material and construction methods)

- legislation and regulatory measures reducing the noises of car traffic

- careful, intelligent public town planning, including

$\circ$ zoning (separate industrial and living quarters)

○ adequate places for recreational outside activities (parks, swimmingpools etc.)

- limitations on population density in all areas in risk of overpopulation

$\circ$ regulations on the size of apartments, buildings and streets, and for industry (height of chimneys, length of smoke release, smoke control)

- national plans regarding the availability and usage of water

- strict separation of drinking water reservoirs and sewage and the purification of all contaminated water

- use of light coal, oil, gas or electricity for - central - heating

- regular removal of normal waste in metal containers; final discharge according to local conditions and type of waste and after careful analysis.

The program was not universally welcomed. The British Minister of Health believed that "no useful purpose would be served by attempts to formulate an international standard on housing." ${ }^{32}$ And the emphasis on central planning may have raised some eyebrows but it was relatively acceptable in the climate of the Depression era, which both justified and demanded large-scale governmental involvement in social issues.

\section{Health during the Economic Depression}

The Depression which followed the crash of 1929 presented public health experts with a perplexing problem: to identify the health effects of mass unemployment and misery. As a first report on "the economic depression and public health" made clear in 1932, this task was far from easy. The enormous scope of the crisis was beyond doubt: counting unemployed and their dependents, the report estimated that 50-60 million people were affected worldwide by unemployment. However, available mortality and morbidity data did not, so far, reveal any tangible effect on public health. ${ }^{33}$ Discussions in the Health Committee confirmed the general bewilderment: "From every country comes the same story - official statistics reveal a

32 Internal memo of the British Ministry of Health, untitled, signed E.H.Y., 9 Jan 1935, Public Record Office, FO 371/19650.

33 "The Economic Depression and Public Health", Memorandum prepared by the Health Section, Bulletin of the Health Organisation, Vol. I (1932), 425-476. 
healthier state than ever. And yet the feeling that the crisis must have deleterious effects on health is general..." ${ }^{34}$ Thus, the two obvious tasks were 1 . to identify the problem - if there was one - and 2. to consider appropriate actions.

In October 1932, the LNHO Committee agreed on six topics for immediate cooperative exploration, which reflected the desire to gain an understanding of the situation and to contribute to practical aid:

1. Methods of Statistical Study to Elucidate the Effects of the Economic Crisis on Public Health

2. Ways to Study Individual Nutrition

3. Ways to Safeguard Healthy Nutrition on a Reduced Income

4. Suitable Methods to Safeguard Public Health, in a Period of Economic Crisis, by the Co-ordination of all Public Health Work

5. Public Health Effects of the Exodus of Unemployed from the Towns to Suburban Agglomeration ("Colonisation")

6. Effects of the Economic Crisis on Mental Hygiene ${ }^{35}$

The study groups formed for each issue worked with different degrees of zeal and success. There were hardly any results for mental hygiene, or psychological health. Given the more pressing practical effects on healthcare and nutrition, there seemed less of a perceived urgent need. An initial report did little more than name possible effects (increase of free time, loss of work discipline and possibly a rise in crime) and express a hope to find information in unpublished material by company inspectors or the like. ${ }^{36}$ Work appears not to have progressed any further.

Studies on the wild or planned colonisation of unemployed in housing with small gardens along the fringes of urban areas, were largely limited to gathering experiences from Germany, Scandinavia and, to a lesser extent, from the United States. Findings revealed that the families concerned tended indeed to be better fed than those without these resources. However, disadvantages also became apparent: often there was insufficient sanitary provision, especially, of course, in wild, unorganised settlements. The minimal financial input required from unemployed recipients in order to prevent a character of charity and also to, indeed, help finance schemes, proved unaffordable to the neediest, so that the schemes tended to exclude

34 Boudreau to Strode (RF), 21 Oct 1932, LONA R 5936/8A/39676/39674.

35 See C.725.M.344.1932; compare: Boudreau to Strode, 21 Oct 1932, LONA, R 5936/8A/39676/39674. and Olsen to Tandler, 20 Dec 1932, LONA, R 5936/8A/39809/39676.

36 Influence of the Economic Crisis on Mental Health, C.H. 1112, 1 Nov 1932, LONA, R 5936/8A/39785/39785. 
the group it would have helped most. Besides, industrial workers did not readily adapt themselves to a life of part-time farmers. ${ }^{37}$

Similarly, studies about statistical methods to gain an understanding of the health effects of the depression showed difficulties as much as insights. Theoretical considerations decreed that the effects of unemployment were bound to be indirect and of a long-term character. Therefore, a scientifically sound method would be to study consistent groups of people before, during and after a period of prolonged unemployment. ${ }^{38}$ In practice, such a statistically impeccable method proved nearimpossible to implement. Rather than forming two clearly distinct groups of employed and unemployed, in real life people tended to move in and out groups, as the depression created a market with many in-between shades of partial, temporary and underpaid employment. Nevertheless, in 1933 researchers in Vienna found measurable effects of unemployment, such as stunted growth and reduced weight. ${ }^{39}$ Even more disconcerting, a US study indicated that people who had suffered a drastic loss in economic status, experienced a marked increase in illness. ${ }^{40}$

The issue of the coordination of public health work at a time of economic crisis was more productive. After a period of collecting material and their vivid discussion, the expert group produced a report in late 1933. This report presented an impressive list of potentially money-saving devices, ranging from the standardisation of equipment to leaner hospital management. Above all, it emphasised the value of prevention and warned of the danger of ruthless, short-sighted budget cuts, which would only result in extra costs in the future. Instead, there was a need for intelligent cuts and/or restructuring measures. Such intelligent cuts pre-supposed a definition of priorities, either on specific population groups like children, or on specific programs. In other words, what was needed was a coherent concept of a health system. The report did not prescribe any particular health system relying on either public or private services, though it did recommend a co-ordination of both, as well as compulsory sickness insurance. ${ }^{41}$ As usual, this report was communicated to member governments and also published so that it was theoretically freely available to anyone who was interested. However, in a highly unusual step, this time the Health Section went further and issued a public appeal, not to health administra-

37 Settlements on the Outskirts of Cities: their Relation to the Public Health, C.H./C.E./5, 10 Nov 1932; Report Stadtbauamt Frankfurt, Abteilung Gartenwesen, 10 Dec 1932, LONA, R 5936/8A/39677/39677.

38 Emil E. Roesle, Health Statistics of the Unemployed, C.H./C.E./20, 15 Feb 1933.

39 A. Götzi, W. Kornfeld and E. Nobel, "The Effects of the Economic Depression on the Population of Vienna", The Quarterly Bulletin of the Health Organisation, Vol. III (1934), 461522.

40 Edgar Sydenstricker et al.: Health and the Depression, reprint from the Quarterly Bulletin of the Milbank Memorial Fund, XI (Oct 1933) Nr. 4.

41 "Report on the Best Methods of Safeguarding the Public Health During the Depression", Quarterly Bulletin of the Health Organisation, Vol. II (1933), 286-332. 
tions but directly to "public opinion." Mirroring the findings and sharpening them in the process, the appeal called for the following:

- Cuts only after consideration as part of a comprehensive program

- Recommended: compulsory sickness insurance

- One centralised health organisation rather than a variety of different services

- Rational planning and management of health institutions

- Experience won during depression used for establishing general principles of efficient public health system. ${ }^{42}$

While there are indications that the process of producing both the report and the appeal had been marked by substantial - supposedly political - "obstacles," the direct response was relatively subdued. The British representative in the Health Committee, conservative George Buchanan, vehemently opposed both the report and the appeal and protested against "making the economic crisis a pretext for international action for the rationalisation of all public services." However, he remained isolated while the Committee as a whole voiced agreement. ${ }^{43}$ Indeed, there was one enthusiastic reaction from the health inspector of Algeria, Lasnet, who considered this issue of particular importance for non-European countries. ${ }^{44}$ Preparations to establish national committees for an overview of the entire health system began in Spain, Denmark and England ${ }^{45}$ but there is little indication, that either the report or the appeal provoked extensive reorganisations of health systems. Its significance is therefore difficult to assess. It may have subtly strengthened the position of those people within administrations who aimed at a strong and efficient health policy.

\section{Nutrition}

Meanwhile, the bulk of the studies on health effects of the economic crisis increasingly focused on nutrition and thereby merged with the other ongoing nutrition related studies. The topic had already attracted some, though unsystematic, atten-

42 Appeal to Public Opinion and General Recommendations of the Conference, C.H.1130, Dec 1933.

43 Report to the Council on the Work of the Twentieth Session of the Health Committee, C. 652.M.312.1933.III, pp. 9-10.

44 Lasnet to Olsen, 28 April 1934, LONA, R 6058 / 8A / 9180 / 938.

45 The exact nature of these "obstacles" remains unclear. Boudreau to Cahen Salvador, 14 February 1934, LONA, R 6058/8A/9180/938. 
tion in Geneva since 1925..$^{46}$ Rural hygiene had added another angle. ${ }^{47}$ Concern about the health effects of the economic crisis added a third approach. That nutrition constituted a major problem was perceived as self-evident. Press reports singled out inadequate nutrition as supposedly the most immediate consequence of the depression. ${ }^{48}$ In how far this was true was, once more, a question of intuition rather than firm knowledge. The first task, therefore, was to identify ways to gain more robust information on the nutrition status of different populations.

A conference was called and took place in Berlin in December 1932 and began with some general considerations on the factors to be taken into account in any investigation of health effects of the depression such as its intensity and duration, working conditions, cost of living and general health level. In order to gain more meaningful insight into the existing reality of (mal-)nutrition the conference called for further studies and issued guidelines. Thus, both medical and social studies were recommended, covering a sufficient number of people (at least 1,000 families or $10 \%$ of the population affected by the depression). As a general rule, large-scale investigations would necessitate simple and swiftly applied methods, while smaller medical studies could add clinical criteria. No uniform method was prescribed, it being understood that there was no one exact method, but several approaches were endorsed and publicised. These used combinations of indicators like weight, height, blood content of the skin, amount of subcutaneous fat, water content, muscular development, and, for clinical examinations, nitrogen content of the urine, protein content of serum, pulse after different activities etc. ${ }^{49}$ This appeal was remarkably successful. Within a year research programs were drawn up and put into practice in Austria, Belgium, Germany, Hungary, the Netherlands, Poland, Yugoslavia and, with some changes, in the United States. ${ }^{50}$

Parallel to these schemes, Wallace Aykroyd, member of the Health Section, worked on guidelines regarding a healthy diet on a very restricted budget. This was not an easy task as it necessarily presupposed a number of definitions. What constituted a healthy diet for whom? What were the requirements of male and female adults and children, engaged in various types of work or unemployed, in calories, protein, fat, carbohydrates, vitamins and minerals? What percentage of income

46 See Paul Weindling, "The Role of International Organizations in Setting Nutritional Standards in the 1920s and 1930s", in: Harmke Kamminga and Andrew Cunningham, eds., The Science and Culture of Nutrition, 1840-1940 (Amsterdam, 1995) p. 323.

47 The Problem of Nutrition with Special Reference to Rural Districts, C.H./Hyg.Rur./E.H. 3, 2 April 1935.

48 See The Economic Depression and Public Health, C.H./C.E.1, 8 Nov 1932

49 "The Most Suitable Methods of detecting Malnutrition due to the Economic Depression", (Conference held at Berlin from December 5th to 7th, 1932), Quarterly Bulletin of the Health Organisation, Vol. II (1933), 116-129.

50 "Report of the Health Organisation, Economic Depression and Public Health", in Quarterly Bulletin of the Health Organisation, Vol II (1933), 532. 
could a family spend on food so that it was considered "affordable"? What are the actual prices paid for food in contrast to official prices according to statistical indices? To what extent could needs be temporarily curtailed and for how long to justify the recommendation of an "emergency diet"? To what extent did eating habits and traditions have to be taken into account and to what extent could or should they be changed by health propaganda? These were scientific as well as political questions that could lead directly into an ideological minefield of who was responsible for the well-being of the nations. Its sensitivity was obvious from studies such as one by Paton and Findlay, quoted in Aykroyd's report on "maternal efficiency," which indicated that "the relation of the height and weight of children to the average depended less on income available than on the character of the housewife." 51 Inevitably, working on this subject was a balancing act, naming scientific findings and plausibilities without pretending certainty where there was none but also avoiding polemics without shying away from controversial questions and conclusions. In a report that was published in 1933, Aykroyd made a brief presentation on the contemporary understanding on nutritional needs and compared average and recommended diets for people living on a low income from different countries. ${ }^{52}$ Comparisons between the cost of an assumed adequate diet and unemployment benefits revealed that in England, a family of parents with three children had to spend $63 \%$ of their unemployment allowance on food, and in Germany, a family consisting of a man, his wife and a child of ten year of age had to spend no less than $83 \%$ on food. ${ }^{53}$ Implicitly, these numbers confirmed earlier assumption that parts of the population were bound to be malnourished because they did not have the money to be anything else. Aykroyd tried hard to retain an even-handed approach. He honoured the concept of "maternal efficiency" pointing out that "even where comparatively low income levels are concerned education of mothers is theoretically capable of bringing about dietary amelioration." But his critical stance is clear from his comments on the significance of education during the ongoing crisis:

Tact and skill are obviously needed in preparing propaganda with the object of improving the diet of the necessitous. Such propaganda may easily become insulting if it is directed at a population struggling to feed itself on a totally inadequate wage or allowance. Further, there is implied irony in urging the use of frugal if well-balanced diets in a world suffering from over-production of food-stuffs. ${ }^{54}$

51 W.R. Aykroyd, "Diet in relation to Small Incomes”, Quarterly Bulletin of the Health Organisation, Vol. II (1933), 149. The study quoted was „Poverty, Nutrition, and Growth“, Med. Res. Counc., Spec. Rep. Ser., No. 101, 1926.

52 W. R. Aykroyd, "Diet in relation to Small Incomes", Quarterly Bulletin of the Health Organisation, Vol. II (1933), 130-153.

53 Ibid., p. 148 and 143 respectively.

54 Ibid., p. 150. 
For those so predisposed, the nutrition reports of the Health Organisation could be read as general critiques of existing socio-economic conditions. This tendency continued in a follow-up report which defined nutritional standards, demanding higher minima than prevalent national standards. ${ }^{55}$ After 1935 the program on nutrition divided. The Health Organisation formed a "Technical Commission" that cooperated with various scientific research institutions and focussed on scientific goals like the quantification of nutritional requirements of different age groups and on specific foods, particularly milk. ${ }^{56} \mathrm{~A}$ more comprehensive and political approach was taken by a mixed commission, consisting of members of the LNHO, ILO, the International Agrarian Institute in Rome and the Financial and Economic Section of the League Secretariat. Their report, published and widely distributed in 1937, discussed ways to ensure healthy public nutrition. Echoing Aykroyd's report of 1933 , it stated that the quality of nutrition could be improved by improving knowledge and/or income. Though difficult, improving knowledge was relatively the simpler task. All it needed was more research and an improved communication of the research findings through public education. Income was politically more sensitive. It could be achieved either through economic growth or, if that was not possible (as it supposedly was not during a time of a worldwide economic crisis), it necessitated a redistribution of wealth. The radicalism of this demand was slightly obscured but not really mitigated by a long list of other very practical suggestions to improve the economic side of nutrition: adequate minimal wages; social regulations; school meals for needy or all children; a suitable trade policy which aimed at a maximisation of affordable food rather than national self-sufficiency (a clear snub of Nazi Germany), or agricultural credits which allowed small farmers to invest. ${ }^{57}$

\section{Conclusions}

All of these programs were put to an abrupt halt when war broke out in 1939. Six years later, the basic questions remained, but the LNHO no longer existed and the new institutions, the cold war climate and the discovery of new technologically promising drugs and chemicals like antibiotics and DDT ensured different

55 Et. Burnet, W.R. Aykroyd, "Nutrition and Public Health", Quarterly Bulletin of the Health Organisation, Vol.IV (1935), 232-474; Paul Weindling, Nutritional Standards, pp. 325 and 327.

56 See "Report on the Physiological Basis of Nutrition drawn up by the Technical Commission of the Health Committee", Quarterly Bulletin of the Health Organisation, Vol.V (1936), 391-416.

57 The Relation of Nutrition to Health, Agriculture and Economic Policy, Final Report of the Mixed Committee of the League of Nations, A.13.1937.II.A. Geneva 1937. 
approaches. For many years, the radicalism which questioned the basics of national and international systems was no longer thinkable.

So what was their significance? What did those programs have in common? What did they aim at, and what is their legacy?

At the simplest level, all programs asked what social conditions must exist for people to live a healthy life. Their point of reference was not so much the individual body - though in the last instance all health concerns individual bodies - but the circumstances in which groups lived, which did or did not allow individuals to make certain choices. As such, they demonstrated a holistic understanding of health as an integral component of a complex interactive web of factors which constituted people's lives. In the process, the significance of health was substantially elevated. Since almost everything somehow influenced health and health was somehow part of almost everything else, health became much less clearly defined. It defused into other spheres of life until it became practically synonymous with life itself. This effect was most pronounced with rural hygiene, which was, indeed, found to be so deeply and justifiably ingrained in everyday rural life, that logically the abortive sequence of the European Conference on Rural Hygiene was to concern itself explicitly with "Rural Life". Not all programs went that far but at the very least, all programs integrated considerations of substantial non-health factors, in a narrow sense, particularly economic and social needs as well as political circumstances.

Secondly, all topics touched on questions of social justice and accountability. How much food did a person need? How much room did he deserve? Who was responsible for his fresh air to breathe and for his clean water to drink? Who should pay for infant healthcare? Governments? Economic players? Housewives? Insurances? Voluntary institutions? Very quickly, all studies arrived at issues which questioned the basics of societal structures. The studies drew attention to public health requirements which were frequently not satisfied, and by defining them as needs rather than as personal duties they emphasised what authorities owed to people rather than what populations owed to authorities. Health was a tangible paradigm which made visible the social glue that tied individuals and society together. Inevitably, a critical assessments of the state of that relation entailed re-thinking what combination of rights and duties did, could or should define society.

The judgments implicitly or explicitly passed in the studies and reports aimed at fairness, but they could not be even-handed. All topics involved elements or personal responsibility, but invariably their focus was on social conditions clearly beyond the control of the individual. In listing conditions which every person needed but could not individually ensure, the LNHO program on social medicine formulated an impressive list of goods and services, for which national populations depended on their governments. It was only a small step to arrive at the conclusion that they were entitled to demand them: 
- Minimal Standards for bare necessities ( nutrition and housing);

- Towns that were planned to supply air, space and opportunity for recreation for their inhabitants;

- Minimal Wages which were high enough to allow the purchase of healthy food;

- Clean Water;

- Waste Removal Services;

- General Health Insurance;

- Acces to International Food Markets;

- Access to perinatal care;

- Various Policy Tools which would compensate for differences in food-related purchase powers (credits, school meals, soup kitchens...);

- Health education;

- ... and others.

Together these demands constituted a formidable load on any society of that time but underlying they entailed even more than a collection of tangible goods and services, which sufficient money and competence would supply. In a wider sense, the tangible demands were about the principle of entitlement. The central point was that all these needs were shared by all people, and that, if people were similarly entitled to health, by implication, they must be similarly entitled to food, recreational space and healthcare. This assumption had sensitive implications. Collectively, the studies contained far-reaching immaterial demands:

- a commitment of governments to take responsibility for public welfare;

- accountability of their governments to their people, entailed in making public a wide range of vital statistics;

- equal rights of all members of society to a - relatively high - minimal standards of health read life; and thus, by implication,

- an egalitarian society.

As mentioned, all programs originated from and depended on continual input from national governments. All countries had a lively interest in the topics discussed, as their consistent - though sometimes muted - support of the work demonstrates. ${ }^{58}$

58 There was no official cooperation on the part of those countries that had left the League of Nations, like Germany and Japan. But there are indications that German authorities continued to follow LNHO activities. Iris Borowy, „Freundschaft, Feindschaft, Neutralität? Die 
But presumably, the unexpected width of the studies and the resulting political repercussions made for somewhat ambivalent reactions on the part of European governments of all ideological shades. All could find something to relate to. The expectation that governments take active responsibility for public health did not pose much of a problem for authoritarian systems, such as those in Germany, Russia and Italy, where governmental involvement in public health was considered one of a number of investments in national strength and was therefore accepted as a given. By contrast, the demand would be less acceptable in countries like Great Britain, whose tradition in hands-off liberalism spurred a view in which health was much more of a private affair. Yet, this same tradition eased the understanding of simultaneous demands for free trade, plainly at odds with ambitions towards autarky in the aforementioned countries. The focus on rural hygiene and vital statistics was compatible with the fascist obsession with national earth and peasant mythology. ${ }^{59}$ The emphasis on prevention similarly agreed with totalitarian focus on collective health. Individual rights, including that to make choices tied into democratic values of individualism and freedom. Egalitarianism was reflected in communist theory, though not in Stalinist reality, and it coincided with democratic idealism, but not with the reality of surviving democracies of the time.

In the mixture of different, sometimes radical, often contradictory world-views of the 1930s, the program easily fit in to some extent in all of them in various forms and niches, but did not fit in totally anywhere. It was both attractive and disconcerting. Above all, the studies made it clear that effective public health came with a price. Implementing the practical recommendations was impossible without adopting some of the underlying belief system. Improving public health meant questioning basic assumptions of existing countries and societies. It meant changing in potentially threatening ways.

The far-reaching character of the underlying demands was not openly discussed. In fact, it may sometimes have been overlooked, because it was not necessarily easy to detect on the basis of individual studies or documents. The masses of paperwork that were produced, and the amount of work spent on minute details, easily obscured that collectively the program expressed fundamental principles. Given more years, the separate projects might have become woven into a coherent unified program on the "social determinants of health." As it was, this process had to wait more than another half century ${ }^{60}$ but even as a sum of isolated projects, the studies contained demands of compelling timelessness. Egalitarianism, particularly, this most difficult demand of all and an old dream of humanity, must have been the

LNHO des Völkerbundes und das Deutsche Reich während des Zweiten Weltkrieges“, in Wolfgang Eckart and Alexander Neumann, eds., Medizin in Deutschland während des Zweiten Weltkrieges, forthcoming.

59 Andrew Heywood, Political Ideologies (Basingstoke, 2nd ed. 1998), pp. 232-233.

60 See below. 
most serious challenge to authorities, then as now. Yet, with the benefit of scores of additional data, recent studies appear to confirm that social equality may, in fact, be the one key factor which determines public health as a whole, particularly but not only that at the lower end of the social strata. ${ }^{61}$

Towards the end of the 1930s, the tangible approach and then the outbreak of World War II considerably reduced interest in interwar social issues in many places. ${ }^{62}$ Nutrition obviously continued to command substantial attention, and LNHO staff contributed their nutrition expertise to allied institutions, though not necessarily as originally intended. ${ }^{63}$ "[B]y painful irony, the scientific standards of diet drawn up by the League were used first by Germany, then by other governments, as a basis for their rationing systems in time of war." ${ }^{\prime 4}$ In the long run, League nutrition work fed into the ever-growing stream of nutrition research, both national and international, which is continuing today. Rural Health and Housing, however, were no issues until after the war, and it is difficult to detect a direct influence of LNHO activities in the fragmented post-war policies, though it is plausible that there was some, as health and planning officers in various countries would be influenced by theses introduced in the public discourse by LNHO publications.

For the most part, the exact effects of interwar activities on social medicine are difficult to define and even more difficult to measure. In the most general terms it can be speculated that they spurred discussions within individual states which, in various forms, eventually contributed to the rise of the welfare state. In some cases, the transmission of ideas can be observed more closely. The British representative at the Geneva discussions on the rational coordination of healthcare systems, Wilson Jameson, went on to have an important role in defining public health. After several more years as Dean of the London School of Hygiene and Tropical Medicine he initiated the so-called "Gasbag Committee" in 1939, a Saturday morning group of prestigious doctors and health experts that discussed issues of public health. Later, he took an active part in the selection and work of several expert committees that surveyed existing hospitals and made suggestions for a restructured hospital system which would integrate traditional voluntary hospitals and elements of further coordination. As chief medical officer in the Ministry of Health during World War II, he was instrumental in organising a national nutrition policy, for which he made

61 Richard G. Wilkinson, The Impact of Inequality: How to Make Sick Societies Healthier (Oxford, 2005); Lawrence A. Jacobs and James A. Morone, Healthy, Wealthy and Fair: Healthcare and the Good Society (Oxford, 2005).

62 Nancy Krieger / Elizabeth Fee, "Measuring Social Inequalities in Health in the Uniter States: A Historical Review, 1900-1950, International Journal of Health Services, 26 (1996), 3, 409.

63 Iris Borowy, "Manoeuvering for Space. International Health Work of the League of Nations during the Second World War", in Susan Gross Solomon, Patrick Zylberman and Lion Murard, eds., "On Shifting Ground:" Health and Space in the Twentieth Century, forthcoming.

64 Frank P. Walters, A History of the League of Nations (Oxford 1952, reprinted 1969), p. 755. 
use, among others, of LNHO interwar studies on nutrition, and he played an important part in the formation of the National Health Service. ${ }^{65}$ Principles of LNHO papers can also be found in the Beveridge Report of 1942. Its medical part was heavily influenced by the Interim Report of the British Medical Association Planning Commission, whose call for better co-ordination of preventive and curative service, for health centres and extended insurance reads like a repetition of LNHO recommendations. though the direct path of influence is difficult to establish. ${ }^{66} \mathrm{~A}$ re-appraisal of the Beveridge Plan in 1994 makes no mention of international sources whatsoever. ${ }^{67}$ A paper by André Shepherd includes the ILO input, which may have served as transmission vehicle of ideas. ${ }^{68}$ As José Harris points out, the Beveridge Report contained little original thought but largely built on widely held views. ${ }^{69}$ It is conceivable, that by that time, principles stated in LNHO commissions had triggered into the general discourse, and were no longer attributed to the LNHO, a discredited institution in England in the 1940s.

What is even more surprising is the degree to which the social medical program in international health policies in the 1930s seems to have been forgotten by today's heirs. A brief historical overview of the developments towards present-day WHO schemes on the social determinants of health mentions Virchow but overlooks the LNHO activities. ${ }^{70}$ However, this does not mean that they have had no legacy. The definition of health in the WHO constitution as "a state of complete physical, mental and social well-being and not merely the absence of disease or infirmity," and other social medical elements derived directly from war-time drafts by LNHO employees. ${ }^{71}$ These traits were eclipsed as politically inopportune during the early Cold War but made a strong, albeit temporary, comeback at the 1978 WHO conference in Alma-Ata with the presentation of the "Health for All" concept. Though the ideas were soon once again sidelined by an upsurge in neo-liberal thinking, they have recently re-emerged. The establishment of a Commission on the Social Determinants of Health in March 2005 testifies to the increased recognition of the

65 Neville M. Goodman, Wilson Jameson. Architect of National Health (London, 1970), 91-94, 111-124; http://www.nhshistory.net/ems 1939-1945.htm, accessed 28 March 2006.

66 Goodman, Wilson Jameson, p. 113-114.

67 W. John Morgen (ed.): The Beveridge Plan 1942-1992. Fifty Years On, Institute of Modern Cultural Studies, (University of Nottingham, 1994).

68 Andrée Shepherd, "Le rapport Beveridge de 1942: Social Insurance and Allied Services,” in J. Carré and J.-P. Révauger, ed., Ecrire la Pauvreté (Paris, 1995), 274.

69 José Harris, "Social planning in war-time: some aspects of the Beveridge Report," in Jay M. Winter, ed., War and economic development: essays in memory of David Joslin (Cambridge, 1975), 239-256.

70 Action on the Social Determinants of Health: Learning from Previous Experiences. Background Paper Prepared for the Commission on Social Determinants of Health, March 2005, WHO, http://www.who.int/social determinants/about/en/.

71 Borowy, Manoeuvering for space. 
social dimension of health. The Commission leaves not doubt about the gravity of the issue concerned: "Evidence shows that most of the global burden of disease and the bulk of health inequalities are caused by social determinants." 72

Supposedly, as the problem of sub-standard health due to poverty, inequality and social injustice remains, so will attempts to address it. Inevitably, the fundamental requirement of reasonably equitable societies will remain the unchanged, as will the tangible requirements of health, access to sufficient healthy food, clean water, housing, health-care and basic security.

At both the most banal and most moving level, the 1930s programs of the LNHO in the field of social medicine have been one step in the long struggle of humanity for a better world.

Iris Borowy is researcher at the Historical Institute, University of Rostock, Germany.

\section{Acknowledgements}

I would like to thank the Deutsche Forschungsgemeinschaft (DFG) for their generous support for the ongoing research on the League of Nations Health Organisation (GR 440/8), which has made work on this paper possible. Likewise, I express my thanks to the anonymous reviewer whose helpful comments have clearly benefited the paper.

72 Action on the Social Determinants of Health: Learning from Previous Experiences. Background Paper Prepared for the Commission on Social Determinants of Health, March 2005, WHO, http://www.who.int/social determinants/about/en/, p. 7. 